Int. J. Electrochem. Sci., 15 (2020) $7310-7325$

\title{
Stress Corrosion Behaviour of a Heating Ageing-treated Al- 4.47Zn-2.13Mg-1.20Cu Alloy in the Presence of Sulfate Reducing Bacteria
}

\author{
Xinyi Liu ${ }^{1}$, Chenchong $\mathrm{Wang}^{2}, \mathrm{Xu}$ Wang ${ }^{1, *}$, Ming $\mathrm{Wu}^{3, *}$, Liang $\mathrm{Li}^{4}$, and Zhihao Zhao ${ }^{3}$ \\ ${ }^{1}$ School of Mechanical Engineering, Liaoning Shihua University, Fushun, Liaoning, 113001, P. R. \\ China \\ ${ }^{2}$ State Key Laboratory of Rolling and Automation, School of Materials Science and Engineering, \\ Northeastern University, Shenyang, Liaoning, 110819, P. R. China \\ ${ }^{3}$ College of Petroleum Engineering, Liaoning Shihua University, Fushun, Liaoning, 113001, P. R. \\ China \\ ${ }^{4}$ Shenyang Aerosun-futai Expansion Joint CO., LTD, Shenyang, Liaoning, 110020, P. R. China \\ *E-mail: wangxu@1npu.edu.cn and wuming0413@163.com
}

doi: $10.20964 / 2020.08 .50$

Received: 30 March 2020 / Accepted: 24 May 2020 / Published: 10 July 2020

\begin{abstract}
The effect of a heating ageing treatment on the stress corrosion cracking (SCC) behaviour of an Al$4.47 \mathrm{Zn}-2.13 \mathrm{Mg}-1.20 \mathrm{Cu}(\mathrm{wt} \%)$ alloy in a simulated seawater solution in the presence and absence of sulfate-reducing bacteria (SRB) was studied by electrochemical techniques and stress corrosion tests. Different heating ageing treatments were applied to the samples. As the ageing rate decreased, the size of the precipitate in grain increased gradually, and the precipitate at the grain boundary displayed a progressively intermittent distribution with a narrow precipitate-free zone, which resisted stress corrosion. As the ageing rate decreased, the stress corrosion cracking susceptibility $\left(\mathrm{I}_{\mathrm{scc}}\right.$ ) of alloy decreased, and the $\mathrm{H} 10$ aged samples in the sterile solution exhibited a minimum $\mathrm{I}_{\mathrm{scc}}$ of $17.3 \%$. In the SRB-inoculated solution, the impedance values of all samples were reduced, and the H10 process exhibited excellent stress corrosion cracking resistance with a low $\mathrm{I}_{\mathrm{scc}}$ of $21.8 \%$. The presence of SRB increased the SCC susceptibility due to the synergistic effect of sulfide produced by SRB metabolism, leading to hydrogen-induced cracking as the main type of stress corrosion of the alloy.
\end{abstract}

Keywords: Al-Zn-Mg-Cu alloy, heating ageing treatment, sulfate-reducing bacteria, stress corrosion

\section{$\underline{\text { FULL TEXT }}$}

(C) 2020 The Authors. Published by ESG (www.electrochemsci.org). This article is an open access article distributed under the terms and conditions of the Creative Commons Attribution license (http://creativecommons.org/licenses/by/4.0/). 